\title{
NASIONALISME DALAM AL-QUR'AN (Studi Tematik Terhadap Ayat-ayat Nasionalisme Perspektif Ahmad Musthafa al-Maraghi)
}

\author{
Nurul Hidayah ${ }^{1)}$, Moh. Jufriyadi Sholeh ${ }^{2)}$, \\ Institut Dirosat Islamiyah Al-Amien Prenduan Sumenep \\ e-mail nurulhidayahalie12@gmail.com, mohjufriyadisholeh@gmail.com
}

\begin{abstract}
ABSTRAK
Di zaman sekarang mulai tumbuh dan berkembang bermacam-macam ideologi yang pro dan kontra terhadap nasionalisme. Nasionalisme ini tidak lepas hubungannya dengan keimanan dan agama. Hal ini dibuktikan dengan penjelasan beberapa ayat al-Qur'an insplisit membahas tentang nasionalisme. Dalam penelitian ini bertujuan untuk mendeskripsikan repsentatif umum nasionalisme menurut Ahmad Musthofa al-Maraghi. Dalam penelitian ini mengggunakan pendekatan kualitatif dengan jenis kajian pustaka yaitu dengan menggunakan metode tematik yang bersifat deskriptif analisis. Dalam pengumpulan data Penelitian ini akan bertumpu sepenuhnya pada tafsir al-Maraghi karya Ahmad Musthofa Al-Maraghi, sebagai sumber primer buku, jurnal-jurnal penelitian sebagai sumber skunder, yang relevan terhadap penelitian ini. Hasil penelitian ini menunjukan repsentatife umum nasionalisme menurut Ahmad musthafa alMaraghi di dalam (QS. al-Anbiya;92), (QS. al-A'raf: 160), (QS. al-Baqarah: 144) ialah nasonalisme yang membangun semangat kebangsaan dengan menjujung tinggi segala jenis peraturan demi memajukan bangsa. Setidaknya terdapat tiga prinsip yang menyamainya sehingga nasionlisme tidak bertentangan dengan al-Qur'an serta syaria't Islam. Yaitu nasionalisme yang berbentuk Persatuan, pengelompokan manusia berdasarkan keturunan dengan menjaga keutuhannya, serta cinta kepada tanah air.
\end{abstract}

Kata Kunci: Nasionalisme, Al-Qur'an, al-Maraghi 


\section{ABSTRACT}

Nowadays, various ideologies that are pro and contra to nationalism have begun to grow and develop. This nationalism cannot be separated from faith and religion. This is evidenced by the explanation of several verses of the alQur'an explicitly discussing nationalism. This study aims to describe the general representative of nationalism according to Ahmad Musthofa alMaraghi. In this study, using a qualitative approach with the type of literature review, namely by using a thematic method that is descriptive analysis. In collecting data, this research will rely entirely on the interpretation of alMaraghi by Ahmad Musthofa Al-Maraghi, as the primary source of books, research journals as secondary sources, which are relevant to this research. The results of this study indicate that the general representation of nationalism according to Ahmad musthafa al-Maraghi in (QS. Al-Anbiya; 92), (QS. Al-A'raf: 160), (QS. Al-Baqarah: 144) is a constructive nationalism. spirit of nationalism by upholding all kinds of regulations for the sake of advancing the nation. There are at least three equal principles so that nationalism does not conflict with the Koran and Islamic syaria. Namely nationalism in the form of unity, the grouping of humans based on descent by maintaining their integrity, as well as love for the homeland.

Keywords: Nationalism, Al-Qur'an, al-Maraghi

\section{A. PENDAHULUAN}

Pembahasan tentang nasionalisme secara tekstual tidak dijelaskan dalam al-Qur'an. akan tetapi sebagian besar menjelaskan tentang jihad di jalan Allah. Ini menjadi isyarat bagi umat Islam pentingnya membangun nasionalisme berlandaskan kitab suci umat Islam. ${ }^{1}$

Gagasan tentang nasionalisme tidak kemas secara langsung oleh al-Qur'an. akan tetapi beberapa ayat al-Qu'ran yang relevan terhadap nasionalisme tersebut. Selain itu pula kisah para Anbiya' pada zaman kenabian merupakan sebagai salah satu bukti bahwasannya nasionalisme ini tidak lepas kaitannya dengan agama. Menurut Hans

${ }^{1}$ Mustaqim, "Bela Negara Dalam Perspektif Al-Qur'an (Sebuah Transformasi Makna Jihad)," 110. 
Kohn nasioanlisme ialah salah satu sikap kepedulian individu terhadap bangsa itu sendiri. ${ }^{2}$

Nasionalisme ialah salah satu sikap cinta tanah air dengan menjujung tinggi segala jenis peraturan dan sikap rela berkorban yang dimiliki oleh suatu bangsa, sikap rela berkorban inilah yang menumbuhkan semangat suatu bangsa dalam memajukan wilayah tersebut.

Disisi lain, nasionalisme menjadi suatu kebutuhan pokok bagi bangsa demi memajukan bangsa dan negara. Paham tersebut memiliki banyak perdebatan. Menurut Bawazir, konsep ini terjadi kontroversi disebabkan karena dua hal: yakni bertentangan dengan kebhinekaan umat islam sehingga tidak ada batasan antar satu daerah tertentu. Selanjutnya dari segi historis nasionalisme berasal dari barat dan identik sebagai hasil dari non muslim kemudian tidak sesuai dengan ajaran di negara islam. ${ }^{3}$

Perdebatan terhadap nasionalisme ini belum ditemukan titik penyelesaiannya disebabkan beberapa pihak yang pro kontra terhadap nasionalisme tersebut. Padahal nasionalisme ini sama sekali tidak bertentangan dengan agama, karena nasionalisme ini bersumber dari agama yang tidak ada bertujuan sebagai pemecah dalam suatu bangsa.

Menurut mufassir Sayyid Qutb, beliau menolak nasionalisme karena berasal dari barat yang terpacu pada kristen selain itu pula nasionalisme ini berupaya untuk memisahkan agama dan masyarakat. ${ }^{4}$ Sedang menurut mufassir Sayyid Qutb, beliau tidak setuju dengan konsep nasionalisme ini disebabkan nasionalisme ini sebagai penyebab adanya pembatas antara agama dan masyarakat. Selain itu pula nasionalisme ini berasal dari barat yang tidak layak dijadikan panutan oleh umat Islam. Selanjutnya beberapa tokoh melontarkan pendapatnya terhadap ketidak setujuannya dalam penerapan konsep nasionalisme di dalam suatu negara. Menurut Daniel Bel dan Habswan nasionalisme

2 Abdul Choliq Murod, "Nasionalisme 'Dalam Prespektif Islam,'” Jurnal Sejarah CITRA LEKHA XVI (2011): 47.

${ }^{3}$ Mustaqim, "Bela Negara Dalam Perspektif Al-Qur'an (Sebuah Transformasi Makna Jihad), 76.

${ }^{4}$ Lufaefi, "Nasionalisme Qur'ani Dan Relevansinya Dengan Semangat Kebangsaan Indonesia: Studi QS.(49): 13, QS.(89): 8, Dan QS.(2): 143," 78. 
bukan menjadi power dalam suatu negara yang demokratis, sehingga nasionalisme ini akan lebih bersifat primitive tidak toleran dengan sifat rasional yang sempit dan terpaku dengan eternisitas. ${ }^{5}$

Di dalam kitab tafsir al-Tahrir wa al-Tanwir KH. Bisri Musthafa, Ibn Asyur dan al-Baidhawi menurut beliau dalam mewujudkan suatu daerah atau wilayah yang maju tiada terlepas dari terselenggaranya keamanan, ketentraman masyarakat di dalam suatu bangsa, serta memohon dan bertumpu sepenuhnya pada Allah SWT. ${ }^{6}$

Selain itu, Tokoh yang pro terhadap nasionalisme ialah alTahtawi beliau mengeluarkan argumennya bahwa patriotisme sebagai sumber kemajuan dan kekuatan suatu negara. Serta sebagai salah satu sarana untuk mengatasi wilayah Islam dan Eropa. Tidak hanya itu beliau juga orang yang sangat berpengaruh terhadap konsep nasionalisme Arab. ${ }^{7}$

Dari berbagai macam penjelasan dan argumen di atas, tentang konsep nasionalisme itulah menjadi inspirasi serta bahan penelitian bagi umat Islam terutama bagi pengkaji al-Qur'an, untuk menemukan deskripsi tentang repsentatif nasionalisme prespektif Ahmad Musthofa al-Maraghi. Sebagaimana di yakini bahwa al-Qur'an sebagai pedoman yang memberikan petunjuk dari berbagai persoalan. Terlebih lagi negara mayoritas muslim, yang di dalamnya menganut konsep nasionalisme.

Sumber data penelitian ini ialah tafsir al-Maraghi, karya Ahmad Musthofa al-Maraghi. Ayat-ayat yang dikaji meliputi tiga ayat yang tersebar dalam tiga surah di dalam al-Qur an, yaitu: (QS. al-Anbiya' 92 dan QS. al-A'raf: 160 QS. al-Baqarah: 144) Peneliti akan membahas bagaimana penafsiran Ahmad Musthafa al-Maraghi terhadap representatife umum. nasionalisme.

\section{B. METODE PENELITIAN}

${ }^{5}$ Une, “Perkembangan Nasionalisme Di Indonesia Dalam Perspektif Sejarah,” 179.

6 Daraini, "Nasionalisme Dalam Perspektif Ibnu A>Syu>R (Kajian Ayat-Ayat Nasionalisme Dalam Tafsir Al-Tahrir Wa Al-Tanwir).," 72.

7 Mugiyono, "Relasi Nasionalisme Dan Islam Serta Pengaruhnya Terhadap Kebangkitan Dunia Islam Global," 6. 
pendekatan yang digunakan dalam penelitian ini ialah kualitatif dengan jenis kajian pustaka menggunakan metode tematik yang bersifat deskriptif analisis. Prosedur penelitian ini akan menggunakan metode analisis tematik dengan cara mempelajari, dan menghimpun ayat alQur'an yang memiliki tujuan yang sama, selanjutnya mufassir mulai memberikan penjelasan serta mengambil kesimpulan. Metode pengumpulan data dalam penelitian ini, akan bertumpu sepenuhnya pada tafsir al-Maraghi, sebagai sumber primer. Serta kitab tafsir lainnya buku-buku, dan jurnal yang relevan terhadap pembahasan tersebut sebagai sumber skunder. ${ }^{8}$

\section{PEMBAHASAN}

\section{Pengertian Nasionalisme}

Kata nasionalisme secara bahasa diambil dari kata "nation" dan "isme"Yang berarti kebangsaan dan aliran atau paham. Sehingga defenisi nasionalisme dalam kamus politik ialah sekelompok masyarakat yang terikat oleh sejarah membentuk satu kesatuan berupa kesatuan wilayah, bahasa, adat istiadat suku bangsa yang diaplikasikan dalam kesatuan budaya. ${ }^{9}$

Rupert Emerson mendefenisikan nasionalisme sebagai sekelompok manusia yang satu jiwa dengan berlandaskan kepada dasar negara yang menyatukan mereka serta menjaga segala sesuatu yang telah diwariskan kepada mereka sebelumnya demi tercapainya cita-cita bersama dalam suatu negara tersebut. Berbeda dengan pendapat Ernest Reman, nasionalisme ialah salah satu unsur yang telah tertera dalam kehidupan bangsa Indonesia dalam bidang sosiopolitik sebagai salah satu alat untuk mendukung terciptanya suatu bangsa yang bersatu untuk memajukan negara tersebut. ${ }^{10}$

Seiring dengan perkembangan waktu nasionalisme memiliki pengertian yang baragam. Sedikitnya di dalam buku karya Tatang Muttaqin, dkk dejelaskan pengertian nasionalisme ialah sebagai pembatas antara satu bangsa dengan bangsa lainnya, selanjutnya nasionalisme ialah sebagai salah satu ideologi serta sebagai salah

${ }^{8}$ Rusmana, Metode Penelitian Al-Qur 'an \& Tafsir, 47.

${ }^{9}$ Darmawijaya, “Islam Dan Nasionalisme Indonesia,” Jurnal ETNOHISTORI, vol.03 (2016), 150.

${ }^{10}$ Mufaizin, “Nasionalisme Dalam Perspektif Alquran Dan Hadits," 43. 
cita-cita bangsa untuk mewujudkan negara yang maju dan tidak tertinggal atau tertindas dari negara lainnya. ${ }^{11}$

Menurut penulis setelah beberapa tokoh telah melontarkan pendapatnya tentang nasionalisme tersebut. Masing-masing mereka memilki makna dan tujuan tersendiri terhadap konsep nasionalisme tersebut. Tujuan yang sama yakni nasionalisme ini sebagai salah satu konsep yang dianut oleh suatu bangsa dengan tujuan untuk mewujudkan cita-cita suatu bangsa. Dari pemaparan makna nasionalisme menurut beberapa tokoh tersebut point pentimg dalam nasionalisme ialah salah satu pembatas antara satu negara dengan yang lainnya, dengan di bubuhi rasa cinta pada tanah air yang memusatkan perhatiannya kepada daerah atau wilayahnya sendiri. Dengan menjujung tinggi semua peraturan hukum-hukum yang terdapat di dalamnya. Tanpa merendahkan negara yang lainnya.

Bentuk-bentuk nasionalisme yang terdapat dalam suatu negara ialah adanya kebenaran di dalam suatu negara tentang politik dari budaya, penyertaan aktif rakyat, dan perwakilan politik. Seperti rakyat Tiongkok yang menganggab bahwa negara sebagai dasar kebudayaan dan agama. ${ }^{12}$

\section{Faktor Penyebab Munculnya Nasionaslisme}

Beberapa penyebab munculnya nasionalisme diantaranya, munculnya nasionalisme disebabkan karena adanya perubahan masyarakat agraris menuju masyarakat industri. Selain itu pula nasionalisme ini muncul sebagai reaksi terhadap penjajahan kolonial, penderitaan di bidang industri, politik, sosial, pendidikan, ekonomi, dan hukum. Serta meningkatnya semangat bangsa meraih kemerdekaan. ${ }^{13}$

Selain faktor yang telah disebutkan di atas, lahirnya nasionalisme ini disebabkan adanya solidaritas dan identitas politik.

11 Tatang Muttaqin,Dkk, Membangun Nasionalisme Baru: Bingkai Ikatan Kebangsaan Indonesia Kontemporer, 1st ed. (Jakarta: Direktorat Kebudayaan, Pariwisata, Pemuda, Dan Olahraga Badan Perencanaan Pembangunan Nasional (Bappenas), 2006), 22.

12 Masroer, "Gagasan Nasionalisme Indonesia Sebagai Negara Bangsa Dan Relevansi Dengan Konstitusi Indonesia,” 232.

${ }^{13}$ Anggraeni Kusumawardani \& Faturochman, "Nasionalisme," Buletin Psikolog, 2004,65 . 
Seperti bangsa Indonesia pernah memiliki kemajuan peradaban di masa lalu, yang kini sudah tidak terlihat wujudnya kembali, akan peradaban Islam itu. Dengan adanya nasionalisme ini akan manunjukkan bahwa negara ini lebih baik dari negara yang lainnya. ${ }^{14}$

Beberapa faktor penyebab munculnya nasionalisme diantaranya ialah perubahan masyararakat agraris menuju industri, sebagai perlawanan terhadap kolonial, penderitaan yang dialami oleh masyarakat di bidang ekonomi, politik, sosial, dan pendidikan. Serta sebagai salah satu bentuk semangat suatu bangsa untuk memperoleh kebebasan dan tidak tertindas dengan segala jenis peraturan yang meresahkan bangsa.

\section{Ayat Al-Qur'an Tentang Nasionalisme}

Secara insplisit al-Qur'an tidak menjelaskan secara langsung istilah nasionalisme di dalam ayat-ayatnya, akan tetapi terdapat beberapa ayat yang mengandung makna nasionalisme diantaranya,

a. Qs. al-Anbiya': 92

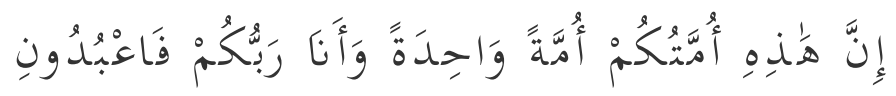

Artinya:

Sesungguhnya agama Tauhid ini adalah agama kaтu sетиa agama yang satu dan aku adalah tuhan-Mu maka sembahlah aku (Qs.al-Anbiya': 92)

b. Qs. al-A'raf: (160)

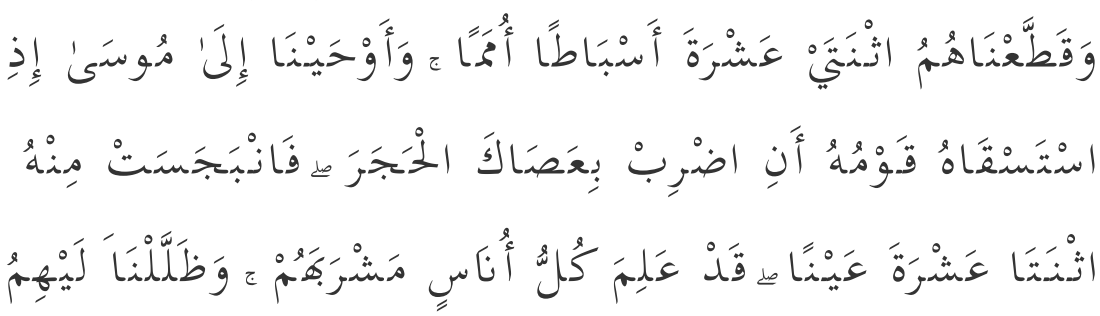

${ }^{14}$ Mifdal Zusron Alfaqi, "Memahami Indonesia Melalui Prespektif Nasionalisme, Politik Identitas, Serta Solidaritas, ” Jurnal Pendidikan Pancasila dan Kewarganegaraan (n.d.), 112. 


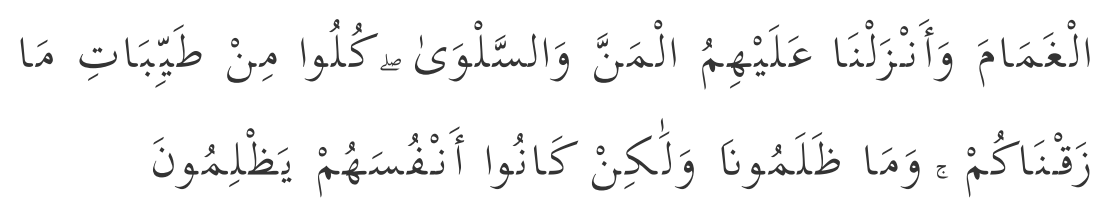

Artinya:

Dan mereka kami bagi menjadi dua belas suku dan masing-masing suku berjumlah besar dan kami wahyukan kepada Musa ketika kaumnya meminta air kepadanya: "pukullah batu itu dengan tongkatmu!. Maka memancarlah dari padanya dua belas mata air, sesungguhnya setiap suku mengetahui tempat minum masingmasing dan Kami naungkan awan di atas mereka dan Kami turunkan kepada mereka manna wa salwa. Dan (Kami firmankan); "Makanlah yang baik-baik dari apa yang telah kmai rezkikan kepadamu'. Mereka tidak Menganiaya Kami, tetapi merekalah yang selalau Menganiaya dirinya sendiri. (Qs. al-A'raf: 160)

c. Qs. al-Baqarah : 144

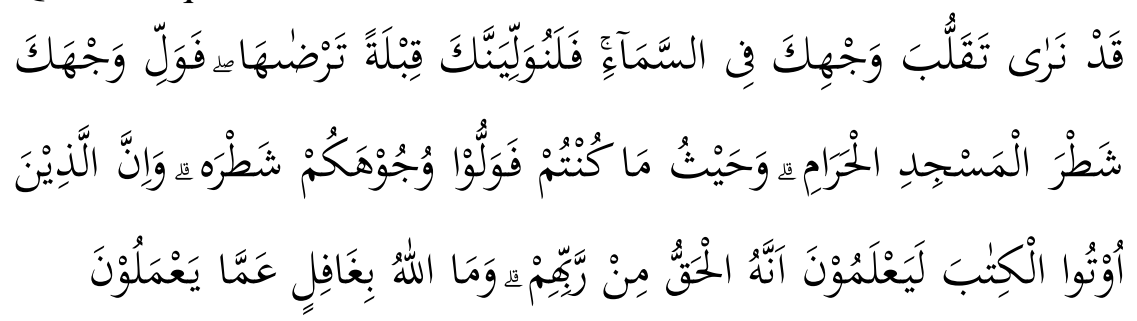

Artinya:

"Sesungguhnya kami sering melihat wajahmu menghadap ke langit, maka sungguh kami akan memindahkan kamu kearah kiblat yang kamu kehendaki. Palingkanlah wajahmu ke Masjidol Haram. Dan dimana saja kamu berada, hadapkanlah wajahmu kearahnya. Dan sesungguhnya orang-orang (yahudi dan nasrani)yang diberi Allah (al-Kitab). Mengetahui bahwa berpaling ke Masjidil Haram ialah benar dari Allah.dan Allah sama seklai tidak luput drai apa yang mereka lakukan” (Qs.al-Baqarah: 144). 


\section{Analisis Ayat Nasionalisme}

a. Qs.al-Anbiya': 92

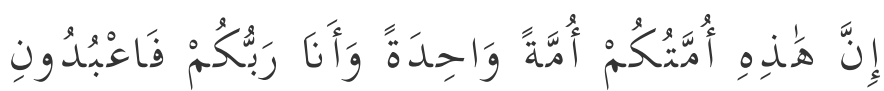

Secara bahasa Kata "ummah " aтma yaummu ummatan, memiliki makna umat, bangsa, atau rakyat. Sedangkan secara terminologi ummat berarti suatu golongan manusia. Serta suatu golongan tersebut dinisbatkan kepada golongan Nabi atau umat tertentu. ${ }^{15}$

Ayat di atas menjelaskan penggunaan dan pengertian "ummat" memiliki makna yang beragam yang tersebar di dalam berbagai surah dan ayat al-Qur'an. Ar-Raghib al-Isfahani mengartikan" ummat" merupakan suatu perkumpulan yang terdapat dalam suatu komunitas tertentu dan memiliki kesesuaian tempat, masa, keyakinan, baik atas kehendak sendiri atau pengelompokkan secara terpaksa. ${ }^{16}$

Sedangkan ukuran bnayaknya tidak disebutkan di dalam al-Qur'an sebagian ra'yi ulama menyebutkan jumlah suatu kelompok ialah empat puluh dan ada yang menyebutkan seratus orang. Al-Qur'an juga memberikan panggilan kata umat untuk orang yang memiliki jasa dan keistemawaan. ${ }^{17}$

Makna kata "ummah" di dalam ayat ini memiliki makna yang berbeda-beda menurut pakar bahasa. Akan tetapi perbedaan tersebut dapat dijadikan argumen "ummah" ialah sekelompok masyarakat dalam membentuk satu kesatuan yang tidak memandang segala jenis perbedaan suku, adat istiadat suatu bangsa tanpa ada paksaan dari orang lain dengan tujuan membentuk suatu kelompok msyarakat yang memiliki satu prinsip dan tujuan yang satu yakni untuk memajukan suatu daerah dan bangsa masing-masing.

${ }^{15}$ Lufaefi, “Nasionalisme Qur'ani Dan Relevansinya Dengan Semangat Kebangsaan Indonesia: Studi QS.(49): 13, QS.(89): 8, Dan QS.(2): 143,” 83.

16 M.Quraishihab, Tafsir Al-Misbah Pesan Kesan Dan Keserasian al-Qur'an, VIII:503.

${ }^{17}$ M.Quraishihab, VIII:503. 
Seperti yang dijelaskan di dalam al-Qur'an surah an-

Nahl : 120

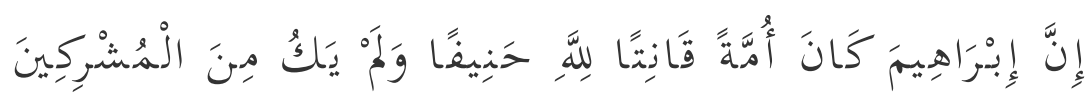

Artinya:

Sesungguhnya Ibrahim ialah seorang yang bisa dijadikan sebagai teladan yang patuh kepada Allah dan hanif. Dan sekeli-kali bukanlah dia termasuk hamba yang menyetkutukan (Allah) (Qs.anNahl: 120)

Menurut Quraishi Shihab, ayat di atas menjelaskan bahwa umat yang satu dalam artian ajaran yang dibawa oleh para Nabi mulai dari Rasul pertama Nuh as sampai dengan rasul yang terakhir Muhammad SAW yang terakhir mengembangkan agama Islam sampai tersebarnya ajaran Islam sampai sekarang ini. Selain itu, di jelaskan dalam kitab tafsir al-Misbah bahwa agama Islam ialah ajaran yang paling dekat dengan jati diri manusia yang disampaikan oleh para Nabi yang disebut sebagai umat, yakni agama untuk kamu (insan) semua umat, yang dimaksud.

Di dalam kitab tafsir al-misbah ayat ini menjelaskan bahwa yang dimaksud dengan umat ialah sekelompok manusia yang membawa kebenaran dan mereka ini dari golongan para nabi sehingga golongan inilah yang menyebarkan ajaran islam dan agama inilah yang paling dekat dengan jati diri manusia.

Umat yang satu dalam artian ajaran yang dibawa oleh para Nabi mulai dari Rasul pertama sampai dengan rasul yang terakhir Muhammad SAW yang terakhir mengembangkan agama Islam sampai tersebarnya ajaran Islam sampai sekarang ini.

Selain itu pula analisis mantan dekan Fakultas Ushuluddin Al-Azhar Mesir Mahmud Hamdi Zaqzuq tahun 1998 beliau menjelaskan al-Qur'an menekankan sifat manusia yang satu, ini juga berarti yang menjadi inti pada ayat ini ialah persatuan bukan penyatuan. ${ }^{18}$

\section{Umat, 442.}

${ }^{18}$ M. Quraish shihab, Wawasan Al-Qur'an Tafsir Tematik Atas Berbagai Persoalan 
Makna umat dalam konteks ini ialah pemeluk agama islam. Dan agama ini ialah agama yang satu berbeda dari segi ajarannya namun mempunyai kesamaan dalam tujuan tersebut dan alQur'an membenarkan persatuan.

Selain itu pula menurut Jamaluddin al-Afghani, menjelaskan bahwa fikiran manusia tidak dituntut supaya orang muslim ini berada dalam satu naungan politik, melainkan demi meraih cita-cita yang sama dan senantiasa menjaga keutuhan negara. ${ }^{19}$

Umat manusia tidaklah dituntut untuk berada dalam satu kesatuan dalam kekuasaan tertentu melainkan lebih mengarahkan umat manusia agar bersatu dalam hal kebaikan dengan satu citacita yang sama dalam suatu bangsa yakni dengan menjujung tinggi segala jenis peraturan dan rambu-rambu dalam suatu wilayah serta menanamkan sikap rela berkorban pada jati diri umat tersebut sehingga menemukan satu tujuan yang sama yakni memajukan wilayah dan daerah tersebut berlandaskan iman dan agama.

b. Qs. al-Baqarah : 144

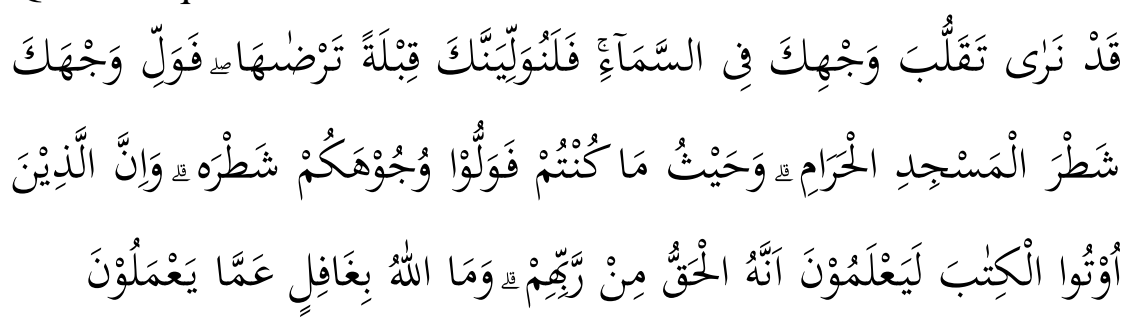

Menurut M.Quraish Shihab menjelaskan surah alBaqarah: 144. aspek nasionalisme yakni cinta pada tanah tumpah darah ini dibuktikan oleh Rasululah SAW. ketika perubahan kiblat dari Baitul Maqdis ke Ka'bah. Disebabkan Ka'bah merupakan kiblat leluhur Nabi Muhammad SAW Serta kebanggaan tersendiri bagi suku Arab cinta tanah air tidak cukup diaplikasikan dengan ungkapan " hubbul wathan minal iman" melainkan justru dibutuhkannya pembuktian dari segi prilaku

${ }^{19}$ M. Quraish shihab, 443. 
dalam kehidupan baik yang dilakukan secara pribadi maupun masyarakat itu sendiri. ${ }^{20}$

Setiap umat memiliki konsep atau pemikiran tersendiri baik dari jenis peraturan dalam kehidupan sehari-hari akan tetapi senantiasa tidak mengutamakan kehendak pribadi melainkan berkiblat kepada satu prinsip yakni dengan tujuan untuk memajukan bangsa serta berlomba-lomba dalam kebaikan demi kesejahteraan umat.

c. Qs. al-A'raf:160

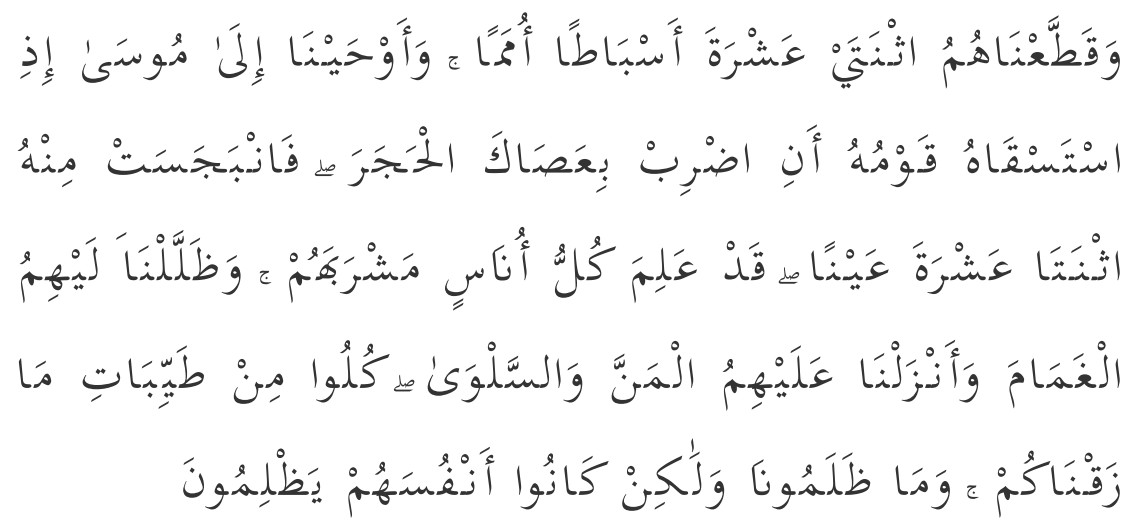

Ayat sebelumnya membahas tentang persatuan serta kecintaan pada tanah air, di dalam ayat ini membahas tentang pengelompokan manusia berdasarkan keturunan. Ini membuktikan bahwa Allah mencipatakan manusia berbangsa-bangsa berdasarkan jenis keturunannya bukan bertujuan untuk saling merendahkan atau meremehkan antara satu dengan yang lainnya, melainkan untuk saling mengenal. Selain itu pula untuk saling meniningkatkan ketakwaan dan pengabdian kepada Allah.

Tujuan Allah menciptakan makhluk berdasarkan keturunan ialah untuk saling mengenal dan tidak menyebabkan pertengkaran dan untuk kemaslahatan bersama, Selain itu pula pengelompokan suatu bangsa berdasarkan keturunan tidak bisa dilakukan jika menyebabkan fanatisme buta terhadap kelompok

${ }^{20}$ M. Quraish shihab, 454. 
lain. Sehingga menimbulkan perpecahan antara satu bangsa dengan bangsa lain.$^{21}$

Nasionalisme merupakan pengelompokkan umat manusia sesuai dengan keturuanan. Dan pengelompokan ini ini tidak bertentangan melainkan inkluisif dengan syari'at islam.

Menurut Ibn Asyur dalam tafsir at-Tahir Wa Tanwir menjelaskan bahwa pentingnya mencaintai tanah air salain itu pula nasionalisme manjadi hal yang penting bagi setiap individu untuk memajukan suatu bangsa. ${ }^{22}$

Menurut Quraishihhab bahwa dalam ayat ini Allah menjelaskan Allah mengelompokkan hambanya berdasarkan kelompok atau keturunannya dengan tujuan untuk saling mengenal serta bukan untuk berpecah belah atau mencari kelemahan satu dengan yang lainnya, serta bukan untuk menjatuhkan dan memenangkan sikap dan cita-cita individual melainkan untuk mencari keridhaan Allah semata dengan pengelompokan berdasarkan keturunan senantiasa memudahkan umat manusia untuk saling mengenal serta berlomba-lomba dalam kebaikan meraih cita-cita bersama tanpa memandang ras, suku, bangsa.

Selanjutnya menurut Ibn Asyur tujuan dibentukanya nasionalisme dalam suatu bangsa ialah untuk menumbuhkan sikap cinta pada tanah aiar dengan sikap rela berkorban serta menjadi kebutuhan pokok untuk memenjukan suatu bangsa.

\section{Nasionalisme Dalam Pandangan Ahmad Mustofa Al-Maraghi} Penafsiran Ayat Nasionalisme Prespektif Al-Maraghi

a. QS. al-Anbiya': 92

Di dalam ayat (Qs. al-Anbiya': 92) ini Allah SWT menjelaskan bahwa pokok penting dalam Agama ialah satu berbentuk ke-Esaan dengan mengesakan Allah semata. Yakni hanya terfokus pada satu tuhan sebagai pememilihara seluruh langit bumi dan seisinya. Oleh sebab itu tidak ada perbedaan diantara manusia kecuali ketakwaaannya kepada Allah. Selain itu

${ }^{21}$ M. Quraish shihab, 448.

${ }^{22}$ Skripsi Oleh, Faiztut Daraini Nasionalisme Dalam Perspektif Ibnu 'A $>$ Syu $>R$ (Kajian Ayat-Ayat Nasionalisme Dalam Tafsir Al-Tahrir Wa Al-Tanwir). Universitas Islam Negeri Sunan Ampel, Surabaya : 2019.66 
pula tidak ada perbedaan antara para nabi meskipun terdapat perbedaan waktu dan tempat hidup para nabi. Sehingga ayat ini menjadi isyarat kepada manusia pentingnya menjaga persatuan antar sesama. Serta tidak berpecah belah dan saling mencaci maki. Melainkan saling menjaga keutuhan dalam persatuan dalam mewujudkan cita-cita bersama. Sama halnya dalam pemasalahan ketatanegaraan, bukan membiarkan sistem ketatanegaraan berjalan tanpa memiliki pedoman syari'at islam serta nash-nash yang shohih. Melainkan berpedoman kepada kisah para nabi yang telah berhasil mengembangkan negaranya. Karena memimpin suatu negara berpedoman kepada Nabi SAW. Serta kisah Nabi Daud dan Sulaiman yang telah dicontohkan sebelumnya. Dan itu semua disertai dengan penuh kesabaran disetiap perbuatan. Sebagaimana yang dikisahkan oleh Nabi Ayyub as. ${ }^{23}$

Di dalam ayat ini menjelaskan kepada kita pentingnya menjaga persatuan diantara kita tanpa melihat sisi perbedaan antara satu dan yang lainnya, karena inti agama di dalam ayat ini ialah persatuan, Dan para nabi tidak mempermasalahkan itu semua meskipun terdapat perbedaan masa antara para anbiya' tersebut, sehingga ayat ini menjadi isyarat kepada kita dalam menjalakan sistem tata negara terutama dalam memimpin suatu bangsa hendaknya memerhtikan dan merenungi ayat ini sebagai pedoman dalam menjalakan segala jenis peraturannya. Menjadikan Agama serta syari'at yang terdapat di dalamnya sebagai landasannya.

Selain itu pula ayat ini memberikan penjelasan tentang permasalahan yang akan dihadapi manusia pada zaman yang akan datang yakni umat Islam akan berceraiberai dan akan terpiah menjadi beberapa golongan dan setiap golongan akan merasakan kebahagian dan pendertiaan masing-masing. Berita ini menjadi berita yang bersifat gaib bagi umat Islam yang kini telah menjadi kenyataan. Umat Islam menjadi berpecah belah menjadi beberapa kelompok dalam bidang politik maupun sosial melalui pemuka

\footnotetext{
${ }^{23}$ Ahmad Musthafa Al-Maraghi, Terjamah Tafsir Al-Maraghi 1115.
} 
agama. Kemudian Allah berpaling dari orang yang berselisih dan masing-masing mereka mengubah urusan dikalangan mereka. ${ }^{24}$

b. Qs. al-A'raf: 160

Dalam ayat tersebut dijelaskan pengelompokan kaum Nabi Musa menjadi dua belas kelompok dan kemudian mereka menjalankan amanah Allah SWT. Untuk menegakkan keadilan. Sebagian dari kelompok mereka yamg memberi petunujuk yang hak kepada manusia dan juga orang-orang dzalim dan kafir. Dan masing-masing mereka punya peraturan tersendiri dalam kehidupan dan urusannya. ${ }^{25}$

Sehingga tidak ada keraguan lagi bahwasannya setiap diri manusia yang menganiaya diri mereka sendiri maka dengan mudahnya menganiaya orang lain. Sama halnya dengan kedzaliman yang dilkukan oleh sesorang pada diri sendiri, keluarga, dan keturunannya. Maka dengan mudah juga mereka untuk melakukannya pada orang disekitar mereka. Dengan cara kufur atas segala nikmat dan pemberian Allah kepada hambanya. Karena mereka berfikir bahwa mereka memberi mamfaat kepada diri sendiri dan keluarganya. ${ }^{26}$

Masing-masing golongan tentunya memiliki peraturan tersendiri dalam menjalankan perintah Allah. Sehingga orang yang telah melakukan suatu perbuatan tentunya dampak tersebut kembali kepada diri mereka sendiri. Sama halnya ketiak seseorang melakukan kedzaliman terhadap diri sendiri maupaun orang lain semua akan mendapat balasan sesaui dengan apa yang telah mereka perbuat.

Dari pemaparan di atas dapat diambil kesimpulan bahwa betapa pentingnya menjaga keluarga dan keturunan agar semua terarah kepada jalan lurus bukan untuk saling mendzolimi antara sesama. Selain itu pula mengelompokkan manusia berdasarkan keturunan untuk memajukan bangsa serta berlombalomba dalam kebaikan.

\footnotetext{
${ }^{24}$ Ahmad Musthafa Al-Maraghi, 116.

${ }^{25}$ Ahmad Musthafa Al-Maraghi, Terjemah Tafsir Al-Maraghi Juz 9, 160.

${ }^{26}$ Ahmad Musthafa Al-Maraghi, 162.
} 
c. Qs. al-Baqarah: 144

Sebelum dipindahkannya arah kiblat dari Baitulmaqdis menuju Masjidil haram ka'bah Di Mekah. Rasul merindukan pertemuan kearah kiblat tersebut. Oleh sebab itu beliau berdo'a agar supaya Allah memindahkan arah kiblat tersebut. Harapan rasul tersebut menjadi kenyataan karena ka'bah ialah kiblat leluhur nabi Ibrahim yang diutus dan dituntut untuk mengajarkan tauhid (membawa dan memperbarui Agama) yang telah dibawa oleh Nabi Ibrahim, dan selain itu Ka'bah itu merupakan kiblat tertua di dunia dan daya tarik bangsa Arab yang beriman kepada risalah Nabi Muhammad Saw. Karena di tangan merekalah maju mundurnya umat dan agama Islam. Dan Ka'bah ialah kebanggan mereka dan tempat itulah tempat yang terlindungi dan aman. ${ }^{27}$

Perpindahahan arah kiblat dari Baitulmaqdis menuju Masjidil Haram ini merupakan penjelasan bahwa ketika mendirikan shalat hal yang diperlukan ialah cukup menghadap kearah kiblat yang diperhitungkan. Dan dimana saja diperbolehkan mereka mendirikan shalat dengan syarat menghadap ke arah kiblat.

Setelah pemaparan diatas dapat dijadikan isyarat bahwa kecintaan pada tanah air di buktikan dengan perbuatan sesorang serta apa yang telah dia berikan kepada tanah air tersebut. Karena menjadi suatu keharusan bagi umat Islam mencintai tanah kelahirannya menjunjung tinggi martabat tanah air tersebut.

\section{KESIMPULAN}

Hasil repsentatif umum nasionalisme perspektif Ahmad Musthofa al-Maraghi ialah sebagai salah satu alat untuk mempersatukan bangsa dengan tidak melihat kepada latar belakang perbedaan ras, suku, bangsa, melainkan berkiblat kepada persatuan umat ini untuk memajukan bangsa.

Selain itu pula nasionalisme tidak bertolak belakang dengan alQur'an melainkan nasionalisme inkluisif di dalamnya, sebagaimana

${ }^{27}$ Ahmad Musthafa Al-Maraghi, Terjemah Tafsir Al-Maraghi 2, 12. 
yang telah dipaparkan pada (QS.al-Anbiya': 92). Menurut Ahmad Musthafa Al-Maraghi nasionalisme ialah persatuan umat yang berpedoman kepada syaria't Islam tanpa memandang segala perbedaan demi memajukan suatu negara. Di dalam (QS. al-A'raf: 160) Nasionalisme ini mengelompokkan manusia berdasarkan keturunan sehingga dapat saling mengenal. Dan di dalam (QS. al-Baqarah: 144) ini menjelaskan tentang cinta pada tanah air merupakan salah satu bentuk konsep nasionalisme dengan menjujung tinggi martabat dan segala jenis peraturan negara tersebut.

\section{DAFTAR PUSTAKA}

Ahmad Musthafa Al-Maraghi. Terjamah Tafsir Al-Maraghi 17. Semarang, 1993.

- Terjemah Tafsir Al-Maraghi 2. Semarang: CV. Toha Putra, 1993.

. Terjemah Tafsir Al-Maraghi Juz 9. Semarang: CV. Toha Putra, 1994.

Alfaqi, Mifdal Zusron. "Memahami Indonesia Melalui Prespektif Nasionalisme, Politik Identitas, Serta Solidaritas." Jurnal Pendidikan Pancasila Dan Kewarganegaraan, n.d.

Anggraeni Kusumawardani \& Faturochman. "Nasionalisme." Buletin Psikolog, 2004.

Choliq Murod, Abdul. 'Nasionalisme ' Dalam Prespektif Islam.' Jurnal Sejarah Citra Lekha XVI (2011).

Daraini, Faizatut. "Nasionalisme Dalam Perspektif Ibnu A $>$ Syu $>$ R (Kajian Ayat-Ayat Nasionalisme Dalam Tafsir Al-Tahrir Wa Al-Tanwir)." UIN Sunan Ampel, 2019.

Darmawijaya. "Islam Dan Nasionalisme Indonesia." Jurnal ETNOHISTORI 03 (2016).

Junaidi, Junaidi. "Pendidikan Islam (Kedudukan dan Jenis Menurut UndangUndang)." Al-Insyiroh: Jurnal Studi Keislaman 1.1 (2015): 105-116.

Lufaefi. "Nasionalisme Qur'ani Dan Relevansinya Dengan Semangat Kebangsaan Indonesia: Studi QS.(49): 13, QS.(89): 8, Dan QS.(2): 143." Jurnal Studi Agama Dan Masyarakat 15 (2019) 
M. Quraish shihab. Wawasan Al-Qur'an Tafsir Tematik Atas Berbagai Persoalan Umat. Bandung: PT. Mizan pustaka, 2013.

Masroer. "Gagasan Nasionalisme Indonesia Sebagai Negara Bangsa Dan Relevansi Dengan Konstitusi Indonesia.” Jurnal Ilmiah Sosiologi Agama Dan Perubahan Sosial 11 (n.d.).

M.Quraishihab. Tafsir Al-Misbah Pesan Kesan Dan Keserasian al-Qur'an. Vol. VIII. Jakarta: Lentera Hati, 2002.

Mufaizin, Mufaizin. "Genealogi Radikalisme Islam Klasik dan

Kontemporer." Al-Insyiroh: Jurnal Studi Keislaman 6.1 (2020): 115126.

Mufaizin. "Nasionalisme Dalam Perspektif Alquran Dan Hadits." Jurnal AlInsyiroh: Jurnal Studi Keislaman 05 (2019).

Mugiyono. "Relasi Nasionalisme Dan Islam Serta Pengaruhnya Terhadap Kebangkitan Dunia Islam Global," n.d.

Mustaqim, Abdul. "Bela Negara Dalam Perspektif Al-Qur'an (Sebuah Transformasi Makna Jihad).” Analisis XI (2011).

Ramdhan, Tri Wahyudi. "Desain Kurikulum pendidikan Islam berbasis tauhid." Al-Insyiroh: Jurnal Studi Keislaman 5.1 (2019): 118-134.

Rusmana, Dadan. Metode Penelitian Al-Qur 'an \& Tafsir. Bandung: CV Pustaka Setia, 2015.

Tatang muttaqin,dkk. Membangun Nasionalisme Baru: Bingkai Ikatan Kebangsaan Indonesia Kontemporer. 1st ed. Jakarta: Direktorat Kebudayaan, Pariwisata, Pemuda, Dan Olahraga Badan Perencanaan Pembangunan Nasional (Bappenas), 2006.

Une, Darwin. "Perkembangan Nasionalisme Di Indonesia Dalam Perspektif Sejarah.” INOVASI 07 (2017). 